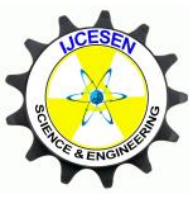

Copyright (C) IJCESEN
International Journal of Computational and

Experimental $\boldsymbol{S}$ cience and Engineering

(IJCESEN)

Vol. 4-No.1 (2018) pp. 24-34

http://dergipark.gov.tr/ijcesen

Research Article

\title{
Sedimentological Study of Balambo Formation at Northeastern Iraq
}

\author{
Enis Kemal SAGULAR ${ }^{1 *}$, Ammar Ramadhan ALGBURI ${ }^{2}$ \\ ${ }^{1}$ Süleyman Demirel Üniversity, Engineering Faculty, Geological Engineering Department, 32260, Isparta-Turkey \\ ${ }^{2}$ Süleyman Demirel Üniversity, Engineering Faculty, Geological Engineering Department, 32260, Isparta-Turkey \\ * Corresponding Author : eniskemal@ gmail.com \\ ORCID: 0000-0002-1277-7269
}

(First received 14 December 2017 and in final form 15 March 2018)

Keywords

Balambo Formation

Facies Analysis

Northern Iraq

Sedimentology

\begin{abstract}
This study was carried out for Balambo Formation (Valanginian - Turonian). Area of study alocated within Azmir anticline at Sulaimaniya area at northeastern Iraq. From petrography study, it was found that the radiolaria forming the main skeletal such as; Novixitus mclaughlini, Archaeodictyomitra simplex, Xitus spinosus, Paronaella ewingi, Cryptamphorella conara, Rhopalosyringium hispidum, Crucella messinae and Vitorfus morini. While the planktonic foraminifera such as; Globigerinelloides bentonensis, Globigerinelloides ultramicus, Planoheterohelix globulosal, Hedbergella (Asterohedbergela), Planomalina buxtorfi, Ticinella praeticinensis and Calcispheres in second order. The ground mass formed of gray to brown micrite. The rocks effected by diagenetic processes with many types like silicification, recrystallization, cementation, and dissolution. According to Microfacies analysis study, the recognized main facies are tow: lime mudstone and lime wackstone. These facies divided into four submicrofacies: radiolarian lime mudstone submicrofacies, calcispheratic lime mudstone submicrofacies, radiolarian lime wackestone submicrofacies and Globigerinelloids lime wackestone submicrofacies. Based on facies and petrographic studies, its deposition within deep sea (Bathyal Zone).
\end{abstract}

\section{Introduction}

Bolton [1] described the Formation as widely exposed at the core of the main anticlines of the Balambo-Tanjero zone and consists of thinbedded limestone with intercalation of dark gray marl and /or shale. The thickness $(315 \mathrm{~m})$ of Balambo Formation is highly variable in type locality (Balambo Mountain) located about $10 \mathrm{~km}$ southeast of Halabcha town. Balambo Formation was first described by Bellen etal [2] from the Sirwan valley, near Halabcha northeastern of Iraq. According to Buday [3] Balambo Formation is equivalent of Sarvak Formation of the east Zagros Mountain in Iran. Al Dulaimi and Mahdi [4], pointed out that the Late Albian-Early Turonian Radiolarians of the Balambo Formation, which were studied from well Jambur-18 (NE of Iraq) are characterized by their abundance and diversity. The studied area is located within Sulaimaniya governorate in northeastern of Iraq, bounded by latitude $\left(35^{\circ}\right.$ $\left.38^{\prime} 31.04^{\prime \prime}\right), \quad\left(35^{\circ} 38^{\prime} 34.55^{\prime \prime}\right)$ North, and longitude $\left(45^{\circ} 28^{\prime} 7.79^{\prime \prime}\right),\left(45^{\circ} 28^{\prime} 32.70^{\prime \prime}\right)$ East. It constitutes part of Zagros mountain belt, where the high mountain chains are northwestsoutheast direction. The outcrops of the Formation are all along the summit of Azmir anticline. In present study one section was selected which was represented by Daraldiyafe section. The studied Balambo Formation is located about $7 \mathrm{~km}$ northeast of Sulaimaniya governorate (Fig. 1). The present study ame to address the facies and sedimentary environment of Balambo formation.

\section{Methods}

The field work includes sampling Balambo Formation chosen from the outcrop in the area for detailed study. Selection of samples from the Formation was based on facies change, colour 


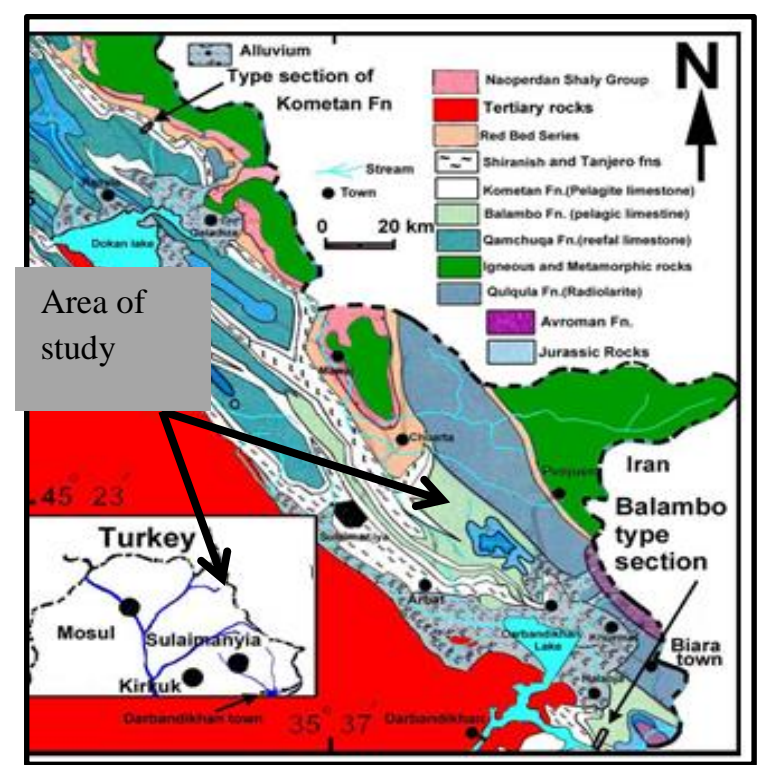

Figure 1: Geological map of Iraq which showing the the studied area, Karim and Ameen [5]

change and differences in other factors. The section is located at the core of Azmir anticline. Thin sections of (57) samples are prepared at the university of Süleyman demirel. They are selected from one section for petrographic study. They were studied under polarized microscope for the identification of the granules constituents and photographing the most useful ones.

\section{Geological and Structural Setting}

The studied area is located in the western zagros fold-thrust belt, directly to the southwest of the main zagros suture zone. Structurally, the area is located within the high folded zone and Imbricated zones (Foreland basin), Buday[6], Alkhadhimi [7], Numan [8] (Fig. 2). According to Ma'ala [9], Azmir mountain is asymmetrical anticline located in the inter mediate zone or in Balambo -Tanjero zone. According to Ma'ala [9], Azmir fold is asymmetrical anticline, directed parallel to Zagros chains extending NW-SE. This anticline exposes the Cretaceous Formations represented by Balambo, Kometan, Shiranish and Tanjero formations. Kometan Formation constitutes the main part of Azmir anticline, while Balambo Formation represents the core of this anticline described as straight and close to the crest line along the anticline extension in addition to the Tertiary units represented by red beds group.

\section{Lithology and Petrography}

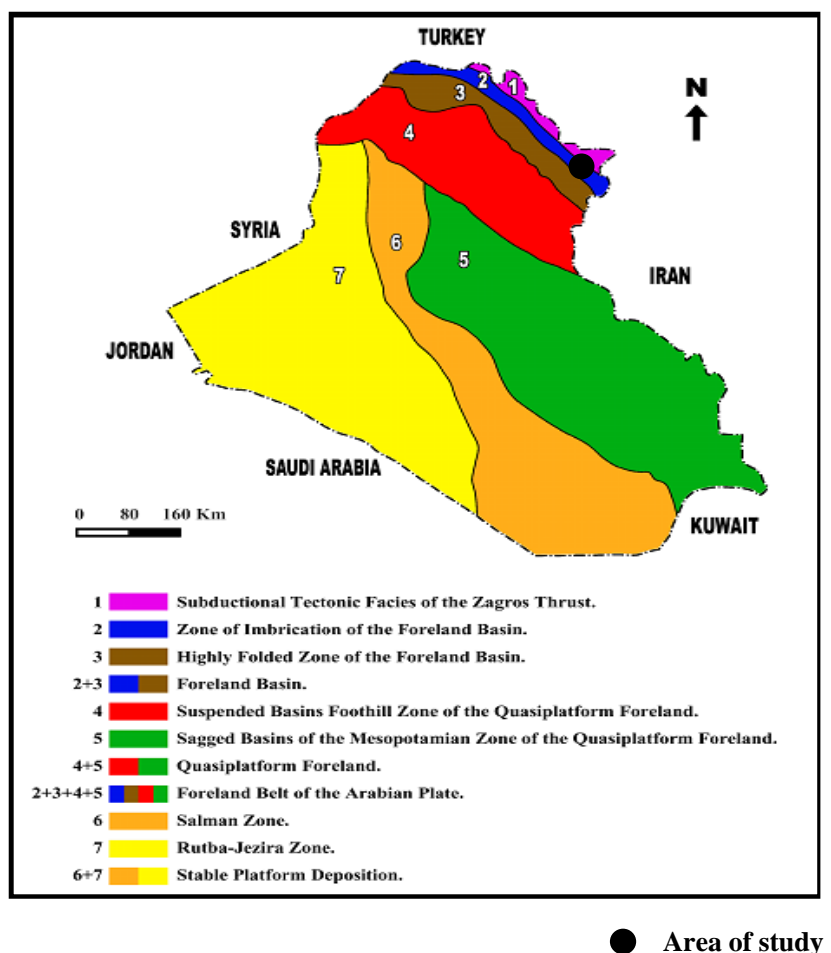

Figure 2: Tectonic map of Iraq which showing the area of study, Numan [8]

The Lithology of the Balambo Formation in present study consist of well-bedded dark gray colour marly limestone, well-bedded yellowish colour limestone, well-bedded dark gray colour marl and dark grayreddish shale (Figure. 3). The lower contact is conformable with Jurassic rocks, Awad [10], and the upper contact with Kometan Formation is gradational. According to Bellen etal [2], assigned Valanginian - Turonian age to the Balambo Formation. The Balambo Formation deposition in study area is found by high content of skeletal grains, compose Radiolarians such as Novixitus mclaughlini, Archaeodictyomitra simplex, Xitus spinosus, Paronaella ewingi, Cryptamphorella conara, Rhopalosyringium hispidum, Crucella messinae and Vitorfus morini (plate.1,2). While the planktonic forms such as; Globigerinelloides bentonensis, Globigerinelloides ultramicus, Planoheterohelix globulosa, Hedbergella (Asterohedbergela), Planomalina buxtorfi, Ticinella praeticinensis and Calcispheres are coming in second order (plate.3,4). The groundmass was formed of micrite, it is associated of the granules. The successions were affected by diagenetic processes with many types like silicification, recrystallization, cementation, and dissolution.

\section{Microfacies Analysis}

Microfacies is regarded as the total of all sediment logical and paleontological data which can be 


\begin{tabular}{|c|c|c|c|}
\hline Age & nation & Thickn & Lithology \\
\hline Cenomaniar & $\begin{array}{l}\text { Kometa } \\
\mathrm{n}\end{array}$ & $22 \mathrm{~m}$ & |س \\
\hline 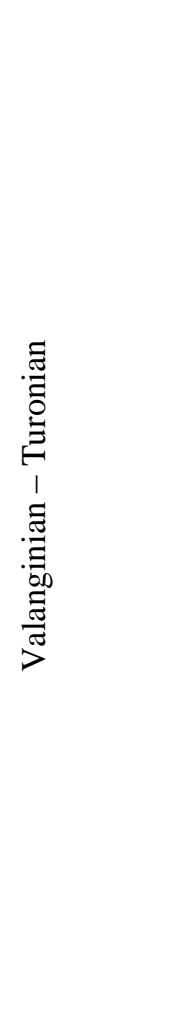 & 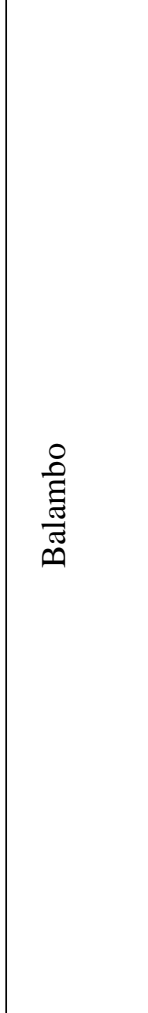 & غூ & 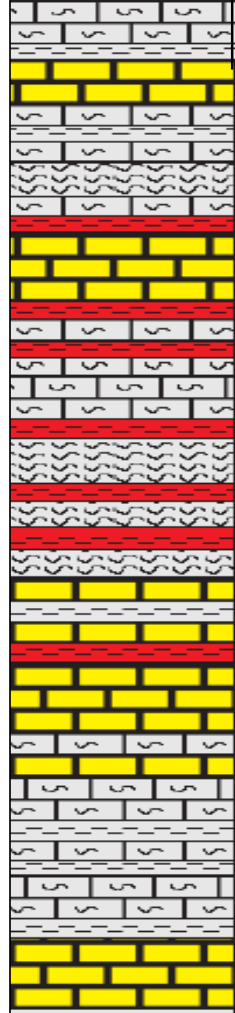 \\
\hline
\end{tabular}

Figure 3: Stratigrahic column of the studied area (not to scale).

described and classified from thin section, peels, polished slabs or rock samples, Flügel [11].Microfacies analysis deals with the; (1) methods of microfacies studies (field work studies, sampling strategies and laboratoy methods relevant to microfacies analysis);(2) qualitative and quantitative microfacies data(matrix and grains, fabrics, grain size analysis); (3)diagenetic criteria ( diagenesis ); (4) limestone classification (name for samples ) and (5) biological controls on the formation of carbonate rocks (biological sediments and fossils in thin section ), Flügel [11]. Carbonate of Balambo Formation were classified according to Dunham [12], classification based on; ground mass, granules and texture, taking into consideration Wilson [13], standard microfacies analysis. The major identified microfacies for the Balambo Formation are; lime mudstone and lime wackstone. Both of them consist of several submicrofacies depending on their components as shown below:

\subsection{Lime Mudstone Microfacies:}

This microfacies is common facies and it is composed essentially of mud matrix and few radiolarians, calcispheres, and planktonic forms. It consists mainly of micrite which is slightly affected by the processes like silicification, recrystallization, cementation, and dissolution.. The mud matrix also consists of clay and iron oxide minerals. lime mudstone microfacies includes each of the following submicrofacies:

\subsubsection{Radiolarian Lime Mudstone Submicrofacies (M1):}

This facies is composed of micrite (more 90\%) with little from: radiolarian, , calcispheres, and planktonic forms content (less than 10\%), usually with dark color. Some of fossils were recognized from Radiolarians such as; Novixitus mclaughlini, Archaeodictyomitra simplex, Xitus spinosus, Paronaella ewingi, Cryptamphorella conara, Rhopalosyringium hispidum and Crucella messinae with little of Calcispheres, and planktonic forms such as; Planoheterohelix globulosa, , Hedbergella (Asterohedbergela) (plate .5.A). This facies has endured diagenetic processes such as silicification, cementation and dissolution. This facies is coinciding with Wilson [13], Standard Microfacies (SMF-3) which belongs to (FZ-1) which was defined (Deep Sea).

\subsubsection{Calcispheratic Lime Mudstone Submicrofacies (M2):}

This facies is composed of micrite (more 90\%) with calcispheres, radiolarian, and planktonic forms content such as; Planomalina buxtorfi, Ticinella praeticinensis (less than 10\%) (plate.5.B). This facies has endured diagenetic processes such as silicification, recrystallization, cementation and dissolution. This facies is coinciding with Wilson [13], Standard Microfacies (SMF-3) which belongs to (FZ-1) which was defined (Deep Sea).

\subsection{Lime Wackestone Microfacies:}

The skeletal component of this facies is up to (15\%); radiolarians, planktonic forms and bioclastic, which are the main one supported by mud (mud supported) .The groundmass is composed of micrite. Wackestone widely distributed in the Balambo formation and the studied section contain this facies. Mineralogical constituents are calcite (micrite) and non-carbonates such as quartz, iron oxides. wackestone microfacies includes each of the following submicrofacies: 


\subsubsection{Radiolarian Submicrofacies (M3): \\ Wackestone}

This facies is characterized by predominant grains has about (10\%-45\%) from rocks component total, and high distribution of Radiolarians such as; Novixitus mclaughlini, Archaeodictyomitra simplex, Xitus spinosus, Paronaella ewingi, Cryptamphorella conara, Rhopalosyringium hispidum, Vitorfus morini and Crucella messinae (plate5. C). Which about $70 \%$ from skeletal grains, it also included Calcispheres with little bioclast. The ground mass content of the micrite with light brown to dark brown. This facies has endured diagenetic processes such as silicification, cementation and dissolution.This facies is equivalent to Wilson [13], Standard Microfacies (SMF-3) which belongs to Facies Zones (FZ-1) described (Deep sea).

\subsubsection{Globigerinelloides wackestone Submicrofacies (M4):}

This facies consist of granules about(12-\%-43\%) from components total of the rock, and the percentage of Globigerinelloides bentonensis and Globigerinelloides ultramicus more than (50\%) from granules component total (plate.5 D). The other skeletal grains are: Planoheterohelix globulosa, Hedbergella (Asterohedbergela), Planomalina buxtorfi, Ticinella praeticinensis with little forms from radiolarians. The ground mass content of the micrite with light brown to dark brown. This facies has endured diagenetic processes such as recrystallization, cementation and dissolution. This facies is equivalent to Wilson [13], Standard Microfacies (SMF-3) which belongs to Facies Zones (FZ-1) described (Deep sea).

\section{Depositional Environment}

Depositional environment is a part of earth surface that has certain chemical, biology, and physical characteristics where sediments are laid on selley [14]. The Balambo Formation was deposited before closing of the new Tethys, which represents the deep southern part from the new Tethys, Ameen and Karim [15], Karim and Surdashy [16 ]. The Balambo Formation interfingering with Sarmord and Qamchuqa Formations in middle of Iraq. The following environmental indicators refer to deep sea environment of Balamo Formation :

1. Balambo Formation characterized by enrichment of Radiolarians assemblages (Ooze), indicate deep marine environment.
2. Accompany of Radiolarian and Calcispheres refer to high quiet deep marine environments, Adams etal [17] Bishop [18].

3. Planktonic foraminifera assemblages are represents open and deep marine environments.

4. The ground mass mainly consists of micrite, with rare sparite, which refer to quiet sedimentary environment.

5. The high thickness of marly limestone, limestone and marl successions represents a deep marine environments.

6. Depending on the Standers Microfacies Wilson [13]. Show that Balambo Formation consist (SMF3 ) which explain one facies zone : (FZ-1) which was defined (Deep Sea), Wilson [13] was developed by Flügel [11]. According to the above discussion the Balambo Formation belong to the deep sea environment (Bathyal Zone) (figure.4).

\section{Conclusion and Results :}

The study was revealed the following results:

1. The main petrographic study of Balambo Formation constituents has shown diversity of Radiolarians such as; Novixitus mclaughlini, Archaeodictyomitra simplex, Xitus spinosus , Paronaella ewingi, Cryptamphorella conara, Rhopalosyringium hispidum, Crucella messinae and Vitorfus morini. In addition to Calcispheres and Planktonic foraminifera such as: Globigerinelloides bentonensis , Globigerinelloides ultramicus, Planoheterohelix globulosa , Hedbergella (Asterohedbergela) , Planomalina buxtorfi , Ticinella praeticinensis.

2. Various Diagenetic processes had influenced carbonates of Balambo Formation, which are: silicification, recrystallization, cementation, and dissolution.

3. The ground mass of Balambo Formation was composed of micrite with light brown to dark color, rich in organic materials.

4. Lithologically, the carbonate rocks of Balambo Formation are composed mainly of, marly limestone, limestone, marl and shell .

5. Microfacies analysis, mainly based on, Dunham [12], has exposed two major microfacies: lime mudstone microfacies and lime wackstone microfacies, whic subdivided into four submicrofacies are:

1. Radiolarian lime mudstone submicrofacies.

2. Calcispheratic lime mudstone submicrofacies.

3. Radiolarian lime wackestone submicrofacies.

4.Globigerinelloids lime wackestone submicrofacies

Depending on to the results of this study, the Balambo Formation represents deep sea (Bathyal) 
environment. This environment was formed during the transgressive, which coverd the passive margine of arabian plate from Valanginian - Turonian age.
Plate 1. Species of radiolarya
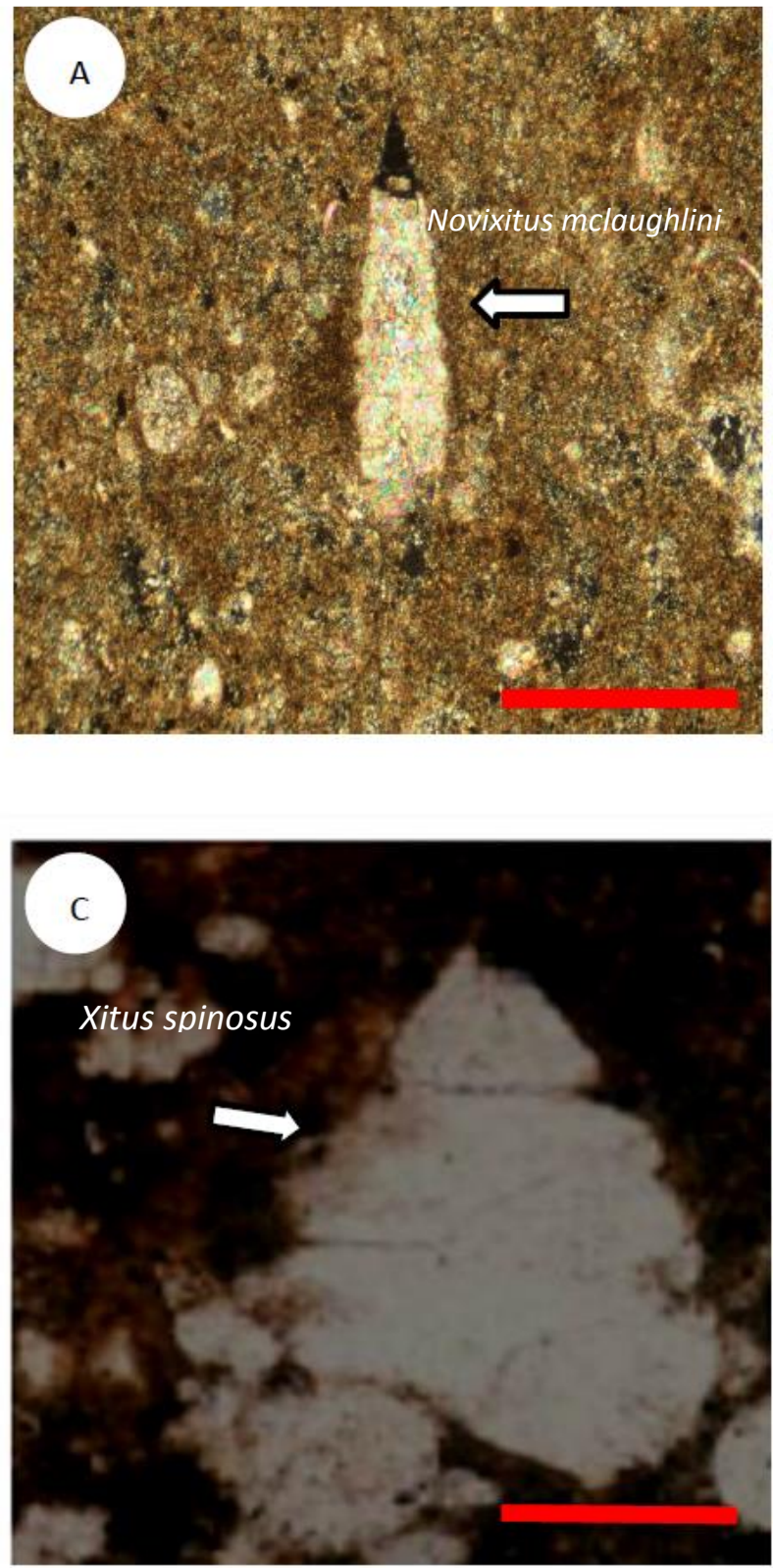
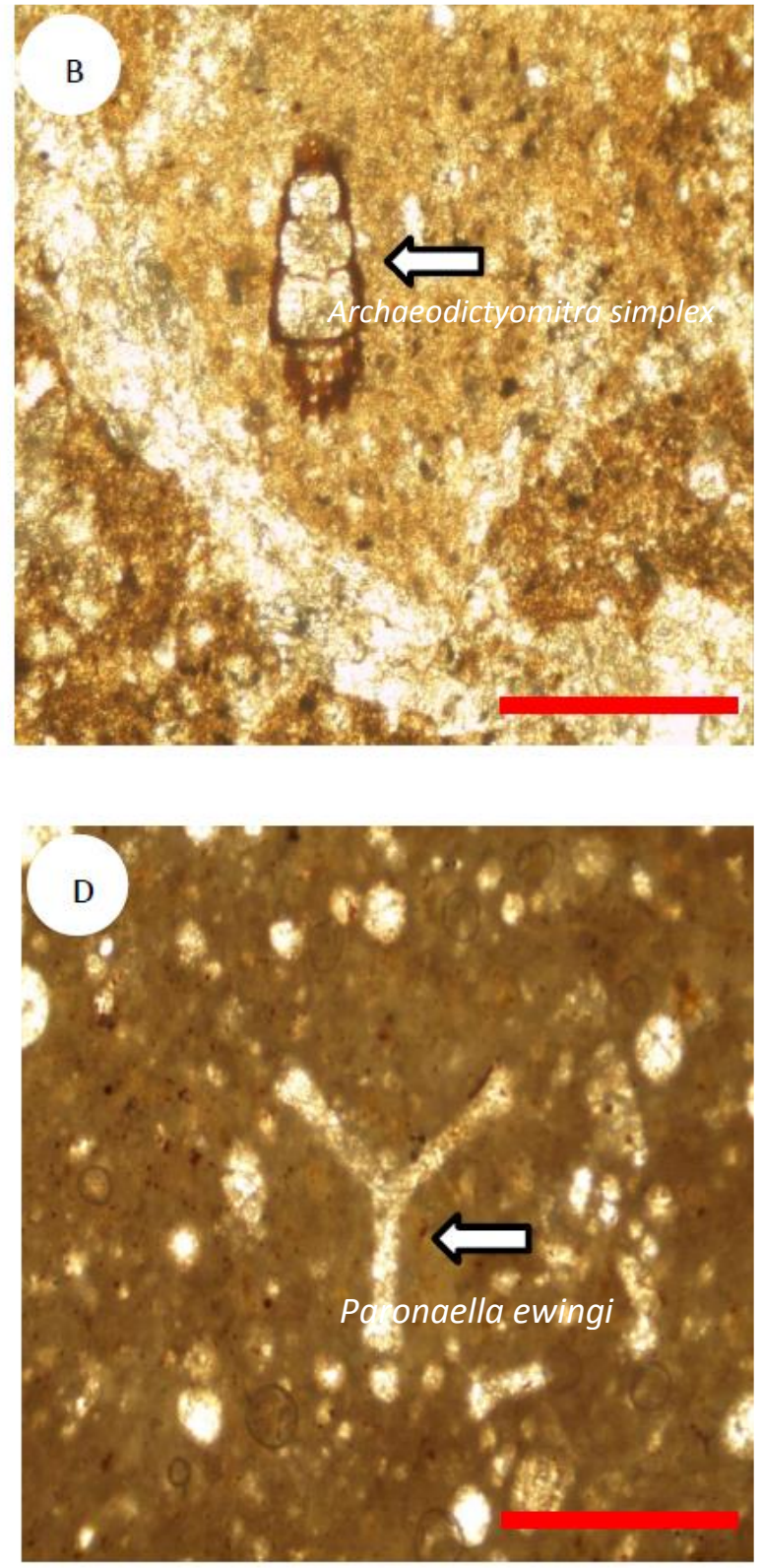

\section{A: Novixitus mclaughlini.}

B: Archaeodictyomitra simplex.

C: Xitus spinosus .

D: Paronaella ewingi

Note: The bar scale is $0.5 \mathrm{~mm}$. 
Plate 2. Species of radiolarya
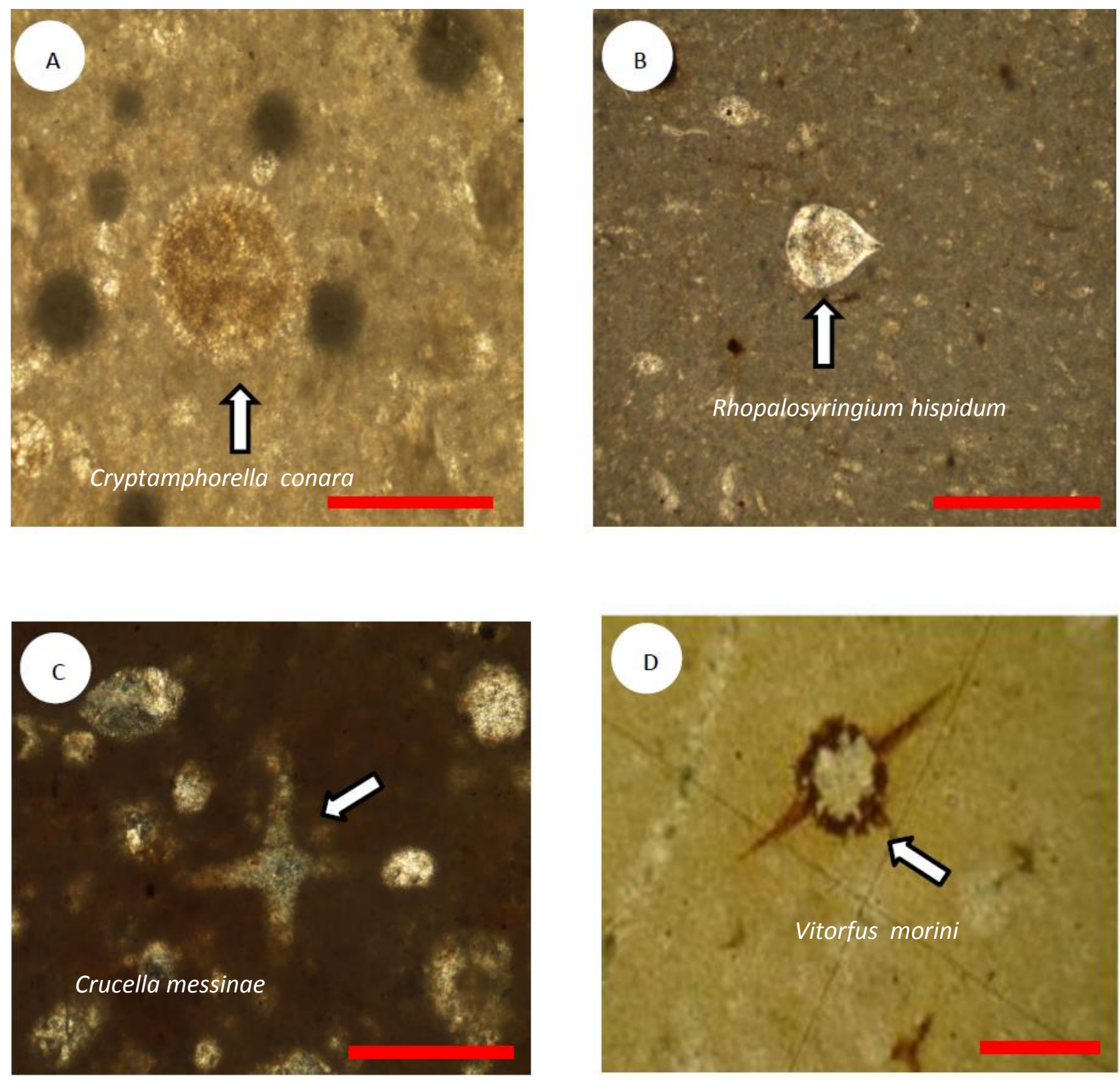

A: Cryptamphorella conara .

B: Rhopalosyringium hispidum .

C: Crucella messinae.

D: Vitorfus morini .

Note: The bar scale is $0.5 \mathrm{~mm}$. 
Plate 3. Calcispheres and Species of planktonic foraminifera
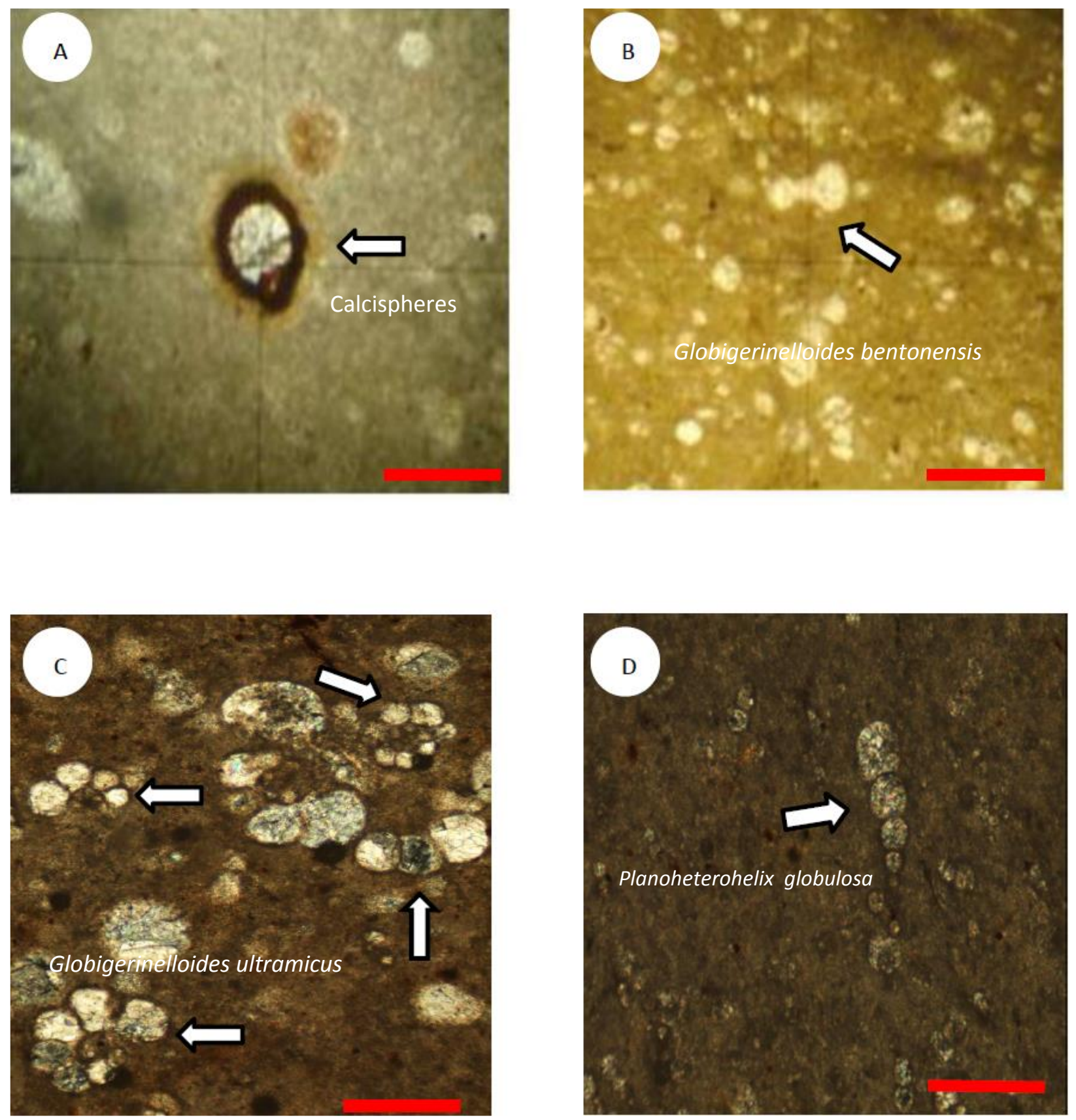

A: Calcispheres.

B: Globigerinelloides bentonensis .

C: Globigerinelloides ultramicus .

D: Planoheterohelix globulosa.

Note: The bar scale is $0.5 \mathrm{~mm}$. 
Plate 4. Species of planktonic foraminifera
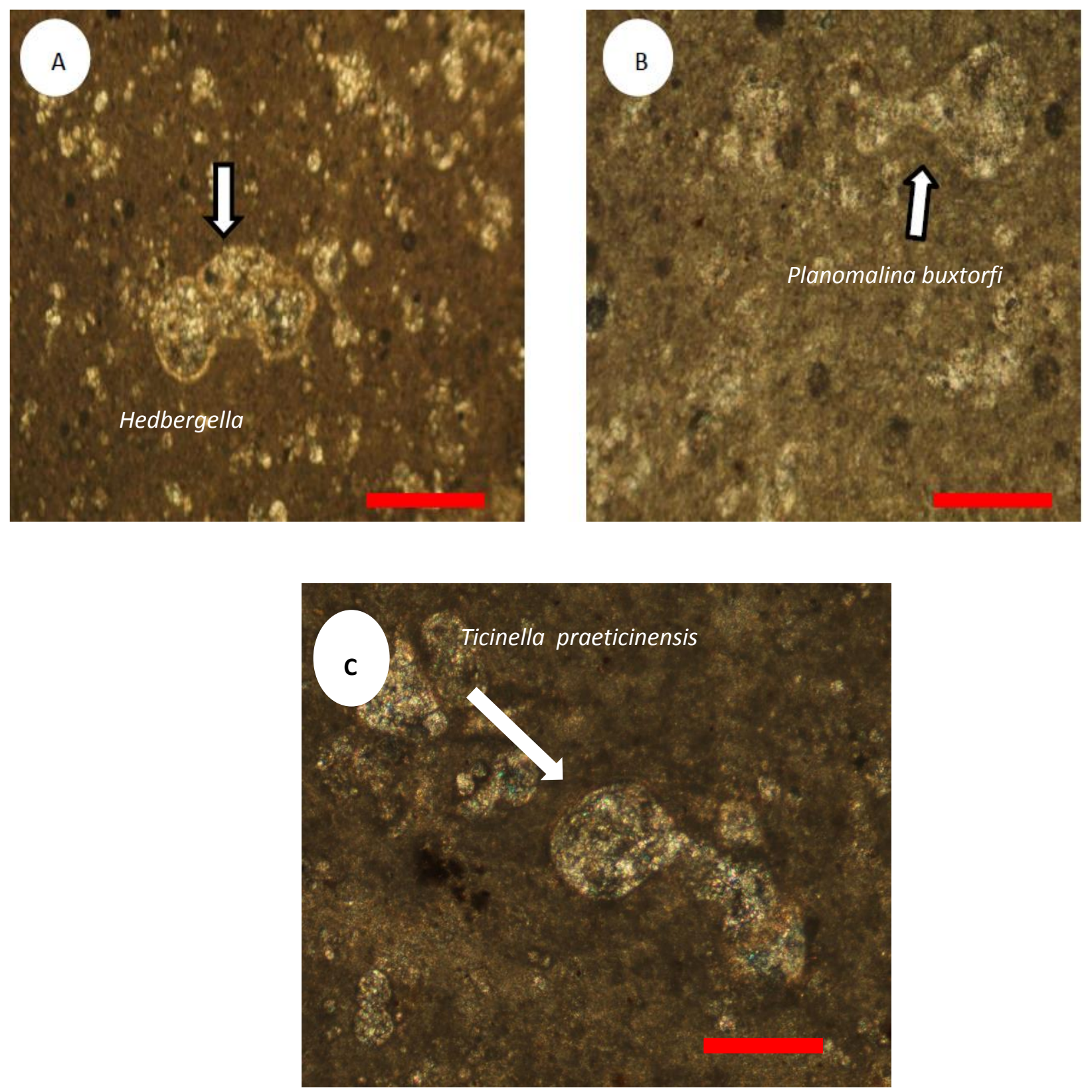

A: Hedbergella. (Asterohedbergela) .

B: Planomalina buxtorfi .

C: Ticinella praeticinensis .

Note: The bar scale is $0.5 \mathrm{~mm}$. 
Plate 5. Submicrofacies of Balambo formation
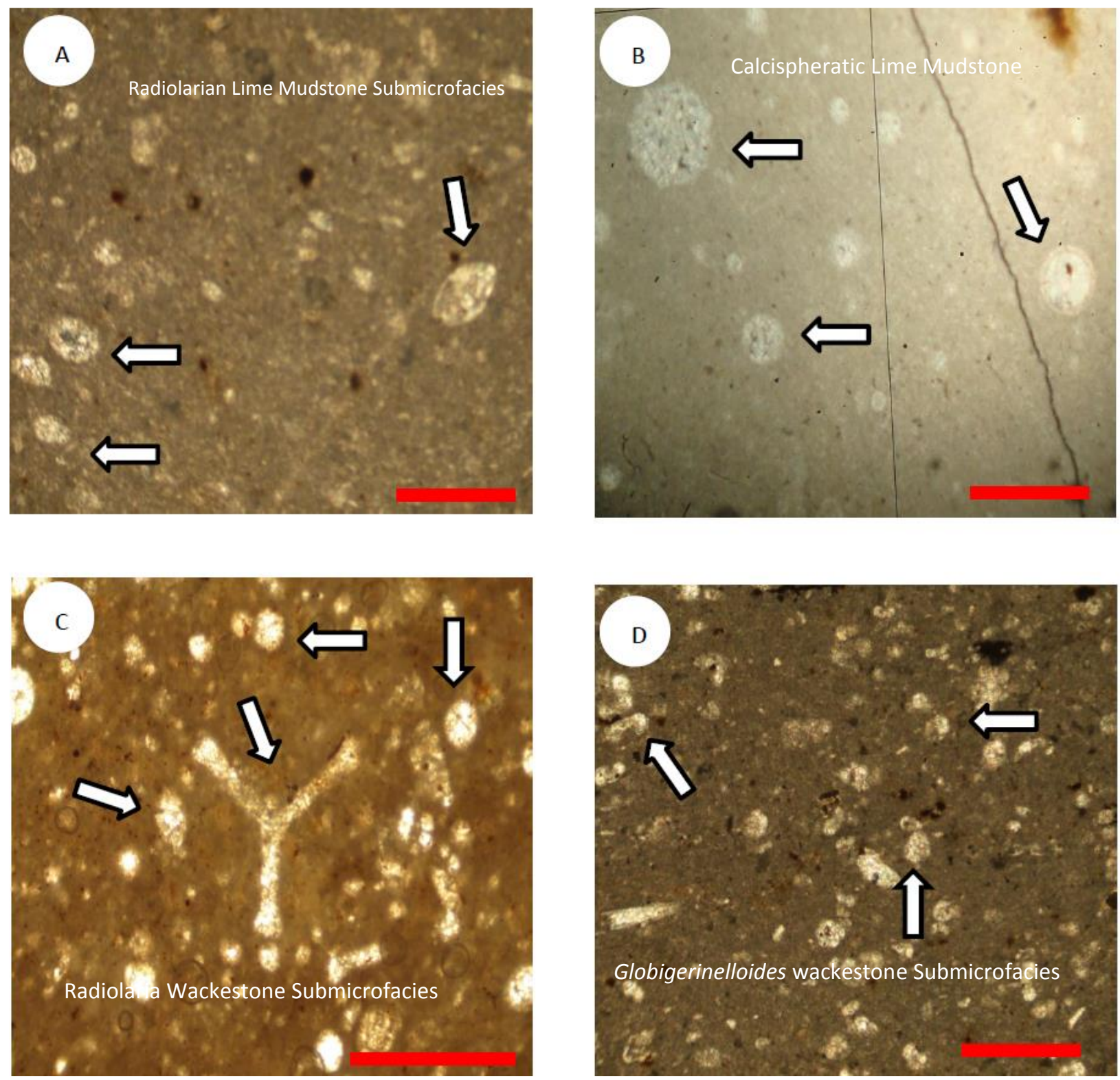
A: Radiolarian Lime Mudstone Submicrofacies.
B: Calcispheratic Lime Mudstone Submicrofacies .
C: Radiolaria Wackestone Submicrofacies.
D: Globigerinelloides wackestone Submicrofacies.
Note: The bar scale is $0.5 \mathrm{~mm}$. 


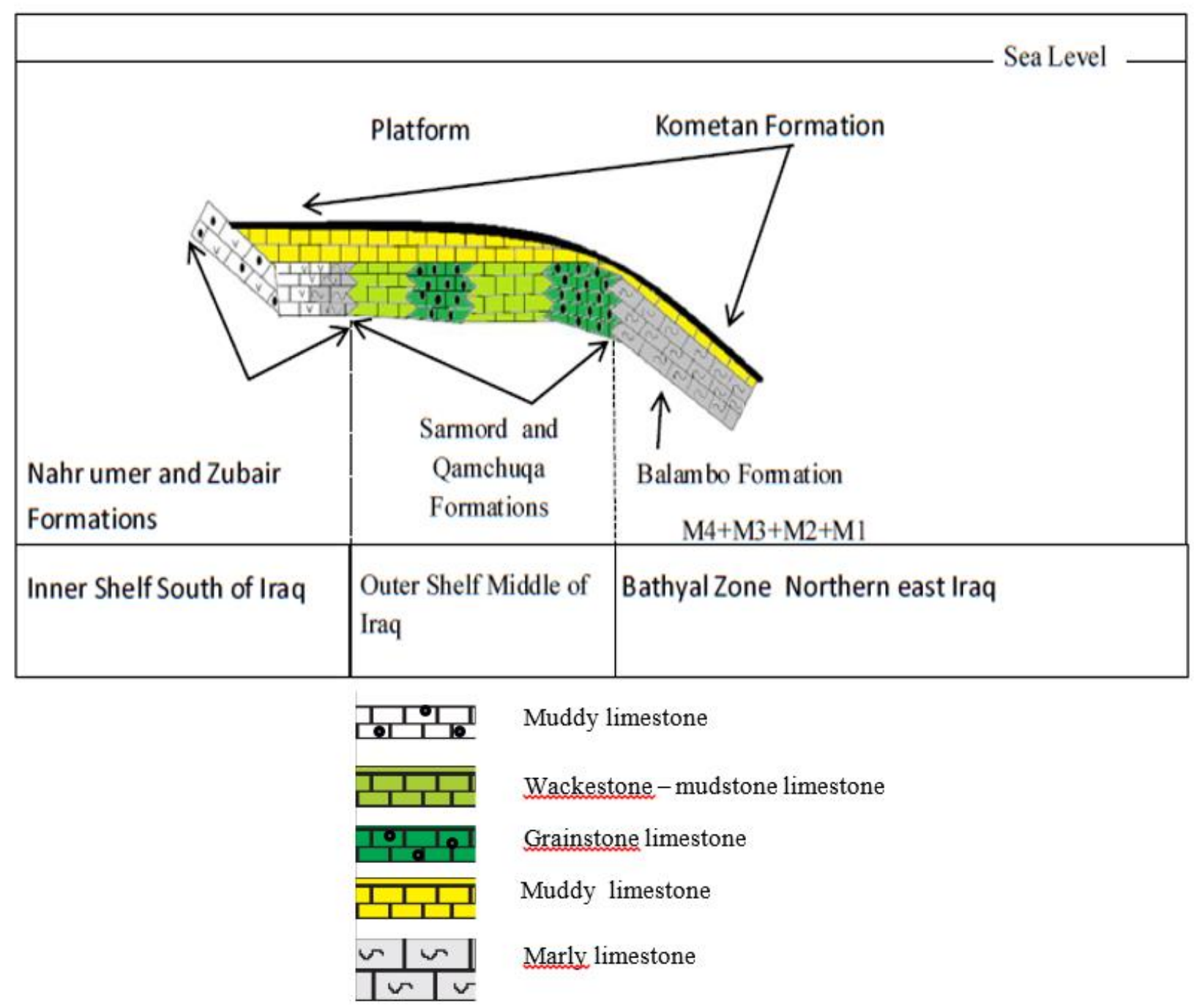

Figuer 4: Deositional model for Balambo Formation

\section{Acknowledgement}

My thanks go to the head of Geology Department Dr. Kamal H. Kareem in University of Sulaimani, during field work. I'd like to thank Mr. Abdulrahaman Bamerni , in Geology Department, University of Dohuk for his help during the diagnosis of fossils .

Finally, I also want to thank University of Süleyman Demirel University /head office, College of Engineering /Geological Engineering Department, for giving me the chance to preparation of the thin-sections.

\section{References}

[1] C.M.G. Bolton, "Geology investigation on the gravel

area between Ad. Dair and Somaika near Baghdad", 1959, Unpubl. Report, NIMCO, Baghdad, Iraq.
[2] Van. R.C. Bellen, H.V.Dunnington, R.Wetzel, D.M.Morton, "Lexique Stratigraphique International Asia, Fascicule, 10a", Iraq, Centeral National deal Recherches Scientifique, Paris, 1959.

[3] T. Buday, "The Regional Geology of Iraq, Stratigraphy and Paleogeography", Dar Al - Kutub Published, Mosul,1980.

[4] S.I. Al-Dulaimi, T.A.Mahdi, "Mid Cretaceous radiolarians from the Balambo Formation NE-Iraq", Iraqi journal of science, Vol.49,2008, pp.132-139.

[5] K.H. Karim, K.M.Ismail, B.M. Ameen, "Lithostratigraphic study of the Contact between Kometan and Shiranish Formations (Upper Cretaceous) from Sulaimani Governorate, Kurdistan Region, NE-Iraq", Iraqi Bulletin of Geology and Mining, Vol.4,2008, pp. 2-17.

[6] T. Buday, S.Z.Jassim, “Tectonic map of Iraq”, 1987, Scale 1:1000000, Geosurvey, Baghdad, Iraq. 
[7] F. Al-khadhimi, V.Sissakian, D.A. Dhikran and A.U. Duraid, "Tectonic Map of Iraq",1996, Geosurvey, Baghdad Iraq.

[8] N.M.S. Numan, "A plate Tectonic Senario for the Phanerozoic Succession in Iraq", Iraqi Geology Journal, Vol.2,1997, pp. 85-110.

[9] K.A. Ma’ ala, K.A. Hassan, A.A.G. Al- khateeb, “ Semi-detailed geological survey of jabal Azmir Choarta area", state company of geological survey and mining, 2004 Report No.2885.

[10] A.M. Awad, "Mineralogical and Geochemical study of Balambo Formation, Sulaimaniya area", Master thesis, Baghdad University - Faculty of Science, 2010

[11] E. Flügel, "Microfacies of Carbonate Rock, Analysis, Interpretation and Application”, SpringerVerlag, Berlin, 2004.

[12] R.J. Dunham, "Classification of Carbonate Rocks According to Depositional Texture",in: Ham, W.E. (eds.), Classification of Carbonate rocks, A.A.P.G.Memoir - 1, Tulsa, Okla, 1962.

[13] J.L. Wilson, "Carbonate Facies in Geologic History", Springer-Verlag, Berl in, 1975.

[14] R.C. Selley, "Applied Sedimentology", Academic Press, 2000.

[15] B.M. Ameen, K.H. Karim, "Depositional environment of Early Cretaceous Arabian Platform: An Eexample from Kurdistan region, NE-Iraq", Proceeding of 3rd scientific conference of the College of Science, University of Baghdad, 2009,pp. 19491961.

[16] H. K. Karim. A.M.Surdashy, "Tectonic and depositional history of Upper Cretaceous Tanjero Formation in Sulaimaniya Area, NE-Iraq", Journal of Zankoy Sulaimani, Vol.8, 2005, pp.47-61.

[17] T.D.Adams, M. Khalili, M.K.Said, "Stratigraphic Significance of Some Oligosteginid Assemblages from Lurestan Province - Northwest Iran", Micropaleoeontology, Vol. 13, 1967, pp.55-67.

[18] B.A. Bishop, "Petrography and origin of Cretaceous limestones - Sierra De Picachos and Vicinity, Nuevo Leon,Mexico", Journal of Sedimmentology Petro., Vol.42,1972, pp.270-286. 